\title{
Front Matter: Volume 8358
}

, "Front Matter: Volume 8358," Proc. SPIE 8358, Chemical, Biological, Radiological, Nuclear, and Explosives (CBRNE) Sensing XIII, 835801 (10 July 2012); doi: $10.1117 / 12.977748$

Event: SPIE Defense, Security, and Sensing, 2012, Baltimore, Maryland, United States 


\title{
PROCEEDINGS OF SPIE
}

\section{Chemical, Biological, Radiological, Nuclear, and Explosives (CBRNE) Sensing XIII}

\author{
Augustus Way Fountain III \\ Editor
}

24-27 April 2012

Baltimore, Maryland, United States

Sponsored and Published by

SPIE

Volume 8358 
The papers included in this volume were part of the technical conference cited on the cover and title page. Papers were selected and subject to review by the editors and conference program committee. Some conference presentations may not be available for publication. The papers published in these proceedings reflect the work and thoughts of the authors and are published herein as submitted. The publisher is not responsible for the validity of the information or for any outcomes resulting from reliance thereon.

Please use the following format to cite material from this book:

Author(s), "Title of Paper," in Chemical, Biological, Radiological, Nuclear, and Explosives (CBRNE) Sensing XIII, edited by Augustus Way Fountain III, Proceedings of SPIE Vol. 8358 (SPIE, Bellingham, WA, 2012) Article CID Number.

ISSN 0277-786X

ISBN 9780819490360

Published by

SPIE

P.O. Box 10, Bellingham, Washington 98227-0010 USA

Telephone +1 3606763290 (Pacific Time) · Fax +1 3606471445

SPIE.org

Copyright (C) 2012, Society of Photo-Optical Instrumentation Engineers

Copying of material in this book for internal or personal use, or for the internal or personal use of specific clients, beyond the fair use provisions granted by the U.S. Copyright Law is authorized by SPIE subject to payment of copying fees. The Transactional Reporting Service base fee for this volume is $\$ 18.00$ per article (or portion thereof), which should be paid directly to the Copyright Clearance Center (CCC), 222 Rosewood Drive, Danvers, MA 01923. Payment may also be made electronically through CCC Online at copyright.com. Other copying for republication, resale, advertising or promotion, or any form of systematic or multiple reproduction of any material in this book is prohibited except with permission in writing from the publisher. The CCC fee code is 0277-786X/12/\$18.00.

Printed in the United States of America.

Publication of record for individual papers is online in the SPIE Digital Library.

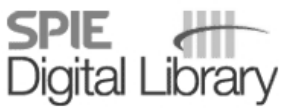

SPIEDigitallibrary.org

Paper Numbering: Proceedings of SPIE follow an e-First publication model, with papers published first online and then in print and on CD-ROM. Papers are published as they are submitted and meet publication criteria. A unique, consistent, permanent citation identifier (CID) number is assigned to each article at the time of the first publication. Utilization of CIDs allows articles to be fully citable as soon as they are published online, and connects the same identifier to all online, print, and electronic versions of the publication. SPIE uses a six-digit CID article numbering system in which:

- The first four digits correspond to the SPIE volume number.

- The last two digits indicate publication order within the volume using a Base 36 numbering system employing both numerals and letters. These two-number sets start with $00,01,02,03,04,05$, $06,07,08,09,0 A, 0 B \ldots 0 Z$, followed by 10-1Z, 20-2Z, etc.

The CID number appears on each page of the manuscript. The complete citation is used on the first page, and an abbreviated version on subsequent pages. Numbers in the index correspond to the last two digits of the six-digit CID number. 


\section{Contents}

ix Conference Committee

xi Introduction

BIOAEROSOL DETECTION STRATEGIES

835804 Ambient background particulate composition, outdoor natural background: interferents/clutter [8358-03]

D. Paterno, U.S. Army Edgewood Chemical Biological Ctr. (United States)

835805 Proposal for a standoff bio-agent detection SWIR/MWIR differential scattering lidar [8358-04] S. Lambert-Girard, Univ. Laval (Canada); N. Hô, B. Bourliaguet, P.-F. Paradis, Institut National d'Optique (Canada); M. Piché, Univ. Laval (Canada); F. Babin, Institut National d'Optique (Canada)

835806 Automated recognition and tracking of aerosol threat plumes with an IR camera pod [8358-05]

R. Fauth, C. Powell, T. Gruber, MESH, Inc. (United States); D. Clapp, Ipswich Engineering (United States)

835807 In silico design of smart binders to anthrax PA [8358-06]

M. Sellers, M. M. Hurley, U.S. Army Research Lab. (United States)

BIOSURVEILLANCE AND BIOSENSING

835809 Novel utilization of the outer membrane proteins for the identification and differentiation of pathogenic versus nonpathogenic microbial strains using mass spectrometry-based proteomics approach [8358-08]

R. E. Jabbour, M. Wade, U.S. Army Edgewood Chemical Biological Ctr. (United States);

S. V. Deshpande, Science \& Technology Corp. (United States); P. McCubbin, OptiMetrics, Inc. (United States); A. P. Snyder, V. Bevilacqua, U.S. Army Edgewood Chemical Biological Ctr. (United States)

8358 OA Development of bacterial display peptides for use in biosensing applications [8358-09] D. N. Stratis-Cullum, J. M. Kogot, M. S. Sellers, M. M. Hurley, D. A. Sarkes, J. M. Pennington, I. Val-Addo, B. L. Adams, U.S. Army Research Lab. (United States); C. R. Warner, J. P. Carney, R. L. Brown, U.S. Army Edgewood Chemical Biological Ctr. (United States); P. M. Pellegrino, U.S. Army Research Lab. (United States)

8358 OB Multi-wavelength resonance Raman spectroscopy of bacteria to study the effects of growth condition [8358-10]

N. Kunapareddy, Research Support Instruments, Inc. (United States); J. Grun, R. Lunsford,

D. Gillis, U.S. Naval Research Lab. (United States); S. Nikitin, Research Support Instruments, Inc. (United States); Z. Wang, U.S. Naval Research Lab. (United States) 
8358 OD Biomolecule Raman spectral temporal flux from resting bacillus spores in deionized water matrix [8358-12]

A. Tripathi, Science Applications International Corp. (United States); R. E. Jabbour, J. A. Guicheteau, P. G. Wilcox, A. P. Snyder, U.S. Army Edgewood Chemical Biological Ctr. (United States)

8358 OE Spectroscopic investigations of surface deposited biological warfare simulants [8358-13] S. J. Barrington, H. Bird, D. Hurst, A. J. S. McIntosh, P. Spencer, S. H. Pelfrey, Defence Science and Technology Lab. (United Kingdom); M. J. Baker, Defence Science and Technology Lab. (United Kingdom) and Univ. of Central Lancashire (United Kingdom)

8358 OG Detection of Bacillus spores within 15 minutes by surface-enhanced Raman spectroscopy [8358-15]

C. Shende, F. Inscore, H. Huang, S. Farquharson, A. Sengupta, Real-Time Analyzers, Inc. (United States)

\section{NOVEL DEVICES FOR BIODETECTION II}

$8358 \mathrm{OH}$ Empirical methods for identifying specific peptide-protein interactions for smart reagent development [8358-16] J. M. Kogot, D. A. Sarkes, D. N. Stratis-Cullum, P. M. Pellegrino, U.S. Army Research Lab. (United States)

8358 0l The use of a handheld Raman system for virus detection [8358-17]

C. Song, The Univ. of Georgia (United States) and Southeast Univ. (China); J. D. Driskell, R. A. Tripp, The Univ. of Georgia (United States); Y. Cui, Southeast Univ. (China); Y. Zhao, The Univ. of Georgia (United States)

$8358 \mathrm{OJ}$ Testing and comparison of the coating materials for immunosensors on QCM [8358-18] A. Oztuna, Gulhane Military Medical Academy (Turkey); H. Nazir, Ankara Univ. (Turkey)

\section{PROXIMAL AND STANDOFF DETECTION OF EXPLOSIVES}

$8358 \mathrm{OL}$ High-resolution optical signatures of fresh and aged explosives in the $420 \mathrm{~nm}$ to $620 \mathrm{~nm}$ illumination range [8358-21]

R. Lunsford, J. Grun, U.S. Naval Research Lab. (United States); J. Gump, U.S. Naval Surface Warfare Ctr. (United States)

8358 OM Use of a spectroscopic lidar for standoff explosives detection through Raman spectra [8358-22]

R. Forest, F. Babin, D. Gay, N. Hô, O. Pancrati, S. Deblois, Institut National d'Optique (Canada), S. Désilets, J. Maheux, Defence Research and Development Canada, Valcartier (Canada)

8358 ON Recent improvements and testing of a check point explosives detection system [8358-23] R. Waterbury, D. Vunck, A. J. Hopkins, K. Pohl, A. Ford, E. Dottery, Alakai Defense Systems, Inc. (United States) 
835800 Standoff detection results with the infrared hyperspectral MoDDIFS sensor [8358-24]

G. Fortin, AEREX Avionics, Inc. (Canada); J.-M. Thériault, Defence Research and Development Canada, Valcartier (Canada); P. Lacasse, AEREX Avionics, Inc. (Canada); F. Bouffard, H. Lavoie, E. Puckrin, S. Desilets, Defence Research and Development Canada, Valcartier (Canada); Y. Montembeault, V. Farley, Telops, Inc. (Canada)

8358 OP Possibilities for standoff Raman detection applications for explosives [8358-25] S. Wallin, A. Pettersson, H. Önnerud, H. Östmark, M. Nordberg, E. Ceco, A. Ehlerding, I. Johansson, P. Käck, Swedish Defence Research Agency (Sweden)

$83580 Q$ Coded-aperture Raman imaging for standoff explosive detection [8358-26] S. T. McCain, B. D. Guenther, Applied Quantum Technologies, Inc. (United States); D. J. Brady, K. Krishnamurthy, R. Willett, Duke Univ. (United States)

8358 OR Coherent anti-stokes Raman spectroscopy for detecting explosives in real time [8358-27] A. Dogariu, Princeton Univ. (United States); A. Pidwerbetsky, LGS Innovations Inc. (United States)

8358 OS Explosives detection and identification using surface plasmon-coupled emission [8358-28] S. Ja, FLIR Systems (United States)

8358 OT Challenges of infrared reflective spectroscopy of solid-phase explosives and chemicals on surfaces [8358-20]

M. C. Phillips, J. D. Suter, B. E. Bernacki, T. J. Johnson, Pacific Northwest National Lab. (United States)

\section{POINT DETECTION OF EXPLOSIVES}

$8358 \mathrm{OU}$ Photo-assisted electrochemical detection (PAED) following HPLC-UV for the determination of nitro explosives and degradation products [8358-30]

J. Fedorowski, W. R. LaCourse, Univ. of Maryland, Baltimore County (United States);

M. M. Lorah, U.S. Geological Survey (United States)

$8358 \mathrm{OV}$ Investigating a drop-on-demand microdispenser for standardized sample preparation [8358-31]

E. L. Holthoff, M. E. Farrell, P. M. Pellegrino, U.S. Army Research Lab. (United States)

8358 0X Multidimensional detection of explosives and explosive signatures via laser electrospray mass spectrometry [8358-33]

J. J. Brady, U.S. Army Research Lab. (United States); P. M. Flanigan IV, J. J. Perez, Temple Univ. (United States); E. J. Judge, Los Alamos National Lab. (United States); R. J. Levis, Temple Univ. (United States)

$8358 \mathrm{OZ}$ Portable thin layer chromatography for field detection of explosives and propellants [8358-35]

J. H. Satcher, J. L. Maienschein, P. F. Pagoria, A. Racoveanu, M. L. Carman, R. E. Whipple,

J. G. Reynolds, Lawrence Livermore National Lab. (United States)

835811 Portable standoff Raman system for fast detection of homemade explosives through glass, plastic, and water [8358-37]

A. K. Misra, S. K. Sharma, T. E. Acosta, J. N. Porter, P. G. Lucey, D. E. Bates, Univ. of Hawai'i (United States) 
835812 Reduced LIBS plasma model via thermodynamics [8358-38]

S. T. Griffin, B. Dent, The Univ. of Memphis (United States)

835813 Real-time residue and powder analysis with laser-assisted infrared imaging [8358-39] M. Weida, P. Mock, P. Buerki, M. Henson, T. Day, Daylight Solutions Inc. (United States)

835815 Plasmonic paper as a highly efficient SERS substrate [8358-41]

C. H. Lee, Washington Univ. in St. Louis (United States); M. E. Hankus, U.S. Army Research Lab. (United States); L. Tian, Washington Univ. in St. Louis (United States); P. M. Pellegrino, U.S. Army Research Lab. (United States); S. Singamaneni, Washington Univ. in St. Lovis (United States)

835816 Next-generation surface-enhanced Raman scattering (SERS) substrates for hazard detection [8358-42]

M. E. Farrell, E. L. Holthoff, P. M. Pellegrino, U.S. Army Research Lab. (United States)

835817 Femtosecond fiber-laser-based, laser-induced breakdown spectroscopy [8358-43]

H. Huang, L.-M. Yang, J. Liu, PolarOnyx, Inc. (United States)

835818 Nondestructive detection and imaging of trace chemicals with high-chemical specificity using single-beam coherent anti-stokes Raman scattering in a standoff configuration [8358-44]

M. T. Bremer, V. V. Lozovoy, M. Dantus, Michigan State Univ. (United States)

8358 1A Improved sensing using simultaneous deep UV Raman and fluorescence detection [8358-46] R. Bhartia, Jet Propulsion Lab. (United States); W. F. Hug, R. D. Reid, Photon Systems, Inc. (United States)

8358 1B Stand-off CWA imaging system: second sight MS [8358-47]

P. F. Bernascolle, A. Elichabe, F. Fervel, J.-B. Haumonté, Bertin Technologies (France)

\section{NOVEL DETECTION STRATEGIES FOR CHEMICAL DETECTION}

8358 1C Selective cavity-enhanced trace gas detection via diffusion time-of-fight [8358-48]

A. Miller, B. Richman, C. R. Viteri, J. McKeever, Entanglement Technologies, Inc. (United States)

8358 1D Detection of trace gases using frequency modulated off-axis cavity ring-down spectroscopy [8358-49]

A. Karpf, G. N. Rao, Adelphi Univ. (United States)

8358 IE Lightweight autonomous chemical identification system (LACIS) [8358-50]

G. Lozos, Smiths Detection (United States); H. Lin, T. Burch, Intelligent Optical Systems, Inc. (United States)

8358 1G A microfluidic toolbox approach to CBRNE sensing [8358-52]

C. Gärtner, R. Klemm, N. Hlawatsch, H. Becker, microfluidic ChipShop GmbH (Germany)

8358 1H Advances in field-portable ion trap GC/MS instrumentation [8358-53]

E. G. Diken, J. Arno, E. Skvorc, D. Manning, G. Andersson, K. Judge, K. Fredeen, Smiths

Detection (United States); C. Sadowski, J. L. Oliphant, S. A. Lammert, J. L. Jones, R. W. Waite,

C. Grant, E. D. Lee, Torion Technologies, Inc. (United States) 
$835811 \quad$ Photoacoustic spectroscopy for chemical detection [8358-54]

E. L. Holthoff, P. M. Pellegrino, U.S. Army Research Lab. (United States)

$83581 \mathrm{~J} \quad$ Real-time quantitative hydrocarbon gas imaging with the gas cloud imager (GCI) [8358-55] N. Hagen, R. T. Kester, C. Walker, Rebellion Photonics, Inc. (United States)

8358 1K Photoacoustic spectroscopy (PAS) system for remote detection of explosives, chemicals, and special nuclear materials [8358-57]

H.-T. Chien, K. Wang, S.-H. Sheen, A. C. P. Raptis, Argonne National Lab. (United States)

\section{RADIOLOGICAL AND NUCLEAR DETECTION}

$8358 \mathrm{lL} \quad$ Possible standoff detection of ionizing radiation using high-power THz electromagnetic waves [8358-58]

G. S. Nusinovich, Univ. of Maryland, College Park (United States); P. Sprangle, U.S. Naval Research Lab. (United States); C. A. Romero-Talamas, J. Rodgers, R. Pu, D. G. Kashyn,

T. M. Antonsen, Jr., V. L. Granatstein, Univ. of Maryland, College Park (United States)

8358 1M Characterization of CdZnTe crystals and radiation detectors [8358-59]

J. Butcher, M. Hamade, M. Petryk, A. E. Bolotnikov, G. S. Camarda, Y. Cui, R. Gul, A. Hossain,

K. H. Kim, G. Yang, R. B. James, Brookhaven National Lab. (United States)

8358 iN Gamma discrimination in pillar structured thermal neutron detectors [8358-60]

Q. Shao, R. P. Radev, A. M. Conway, L. F. Voss, T. F. Wang, R. J. Nikolić, Lawrence Livermore

National Lab. (United States); N. Deo, C. L. Cheung, Univ. of Nebraska-Lincoln (United States)

835810 Coherent $x$-ray scatter projection imaging using an array of monoenergetic pencil beams [8358-62]

K. Landheer, Carleton Univ. (Canada); P. C. Johns, Carleton Univ. (Canada) and Univ. of Ottawa (Canada)

8358 IP MOX assay using He-4 scintillation detectors [8358-63]

D. Murer, Arktis Radiation Detectors Ltd. (Switzerland) and ETH Zurich (Switzerland);

R. Chandra, Arktis Radiation Detectors Ltd. (Switzerland); G. Davatz, H. Friederich, Arktis

Radiation Detectors Ltd. (Switzerland) and ETH Zurich (Switzerland); U. Gendotti, Arktis

Radiation Detectors Ltd. (Switzerland); R. Jebali, Arktis Radiation Detectors Ltd. (Switzerland) and ETH Zurich (Switzerland)

8358 IR Investigations into the polymorphs and hydration products of $\mathrm{UO}_{3}$ [8358-65]

L. E. Sweet, E. C. Buck, C. H. Henager, Jr., S. Hu, D. E. Meier, S. M. Peper, J. M. Schwantes, Y.-F. Su, R. L. Sams, T. A. Blake, T. J. Johnson, Pacific Northwest National Lab. (United States); T. J. Kulp, R. L. Sommers, J. D. Sugar, J. D. Chames, Sandia National Labs., California (United States)

8358 is Thermal neutron detection with PMMA nanocomposites containing dysprosium fluoride nanocrystals [8358-66]

A. C. Rivera, N. N. Glazener, N. C. Cook, S. Maestas, B. A. Akins, L. M. Armijo, J. B. Plumley, N. J. Withers, K. Carpenter, G. A. Smolyakov, R. D. Busch, M. Osiński, The Univ. of New Mexico (United States) 
$83581 \mathrm{~T}$ The use of stimulated electron emission (SEE) in homeland security applications [8358-67]

H. Ing, H. R. Andrews, M. Facina, Bubble Technology Industries, Inc. (Canada); W. T. Lee,

H. W. Niu, Hamilton Sundstrand Space Systems (United States)

\section{POSTER SESSION}

8358 IW I-SCAD® standoff chemical agent detector overview [8358-70]

M. O. Popa, M. T. Griffin, Chemring Detection Systems, Inc. (United States)

$83581 \mathrm{X}$ Micro-optics for simultaneous multi-spectral imaging applied to chemical/biological and IED detection [8358-73]

M. Hinnrichs, Pacific Advanced Technology, Inc. (United States)

83581 IY Influence of spatial differential reflection parameters on 2,4,6- trinitrotoluene (TNT) absorption spectra [8358-74]

T. Dubroca, G. Guetard, R. E. Hummel, Univ. of Florida (United States)

$83581 \mathrm{Z}$ Isolation and characterization of anti-SEB peptides using magnetic sorting and bacterial peptide display library technology [8358-75]

J. M. Pennington, J. M. Kogot, D. A. Sarkes, P. M. Pellegrino, D. N. Stratis-Cullum, U.S. Army Research Lab. (United States)

Author Index 


\title{
Conference Committee
}

\author{
Symposium Chair
}

Kevin P. Meiners, Office of the Secretary of Defense (United States)

Symposium Cochair

Kenneth R. Israel, Lockheed Martin Corporation (United States)

Conference Chair

Augustus Way Fountain III, U.S. Army Edgewood Chemical Biological Center (United States)

Program Committee

Jerome J. Braun, MIT Lincoln Laboratory (United States)

John C. Carrano, Carrano Consulting (United States)

Christopher C. Carter, The Johns Hopkins University Applied Physics Laboratory (United States)

Matthew T. Griffin, General Dynamics Armament and Technical Products (United States)

Jason Guicheteau, U.S. Army Edgewood Chemical Biological Center (United States)

Eric J. Houser, U.S. Department of Homeland Security (United States)

Harry Ing, Bubble Technology Industries, Inc. (Canada)

Harold R. McHugh, U.S. Department of Energy (United States)

Carter D. Hull, Y-12 National Security Complex (United States)

Aaron LaPointe, U.S. Army Night Vision \& Electronic Sensors Directorate (United States)

Paul M. Pellegrino, U.S. Army Research Laboratory (United States)

Michael W. Petryk, Defence Research and Development Canada, Suffield (Canada)

James G. Placke, Jr., Y-12 National Security Complex (United States)

Cynthia R. Swim, U.S. Army Edgewood Chemical Biological Center (United States)

David Taylor, U.S. Department of Homeland Security (United States)

Anna Tedeschi, Strategic Analysis, Inc. (United States) and U.S.

Department of Homeland Security (United States)

Steven W. Waugh, Defense Threat Reduction Agency (United States) 
Session Chairs

Bioaerosol Detection Strategies

Jerome J. Braun, MIT Lincoln Laboratory (United States)

Biosurveillance and Biosensing

Cynthia R. Swim, U.S. Army Edgewood Chemical Biological Center (United States)

Novel Devices for Biodetection I

Steven W. Waugh, Defense Threat Reduction Agency (United States)

Novel Devices for Biodetection II

Steven W. Waugh, Defense Threat Reduction Agency (United States)

Proximal and Standoff Detection of Explosives

Aaron LaPointe, U.S. Army Night Vision \& Electronic Sensors Directorate (United States)

Point Detection of Explosives

Anna Tedeschi, Strategic Analysis, Inc. (United States)

Laser-Based Approaches to Chemical Detection

Paul M. Pellegrino, U.S. Army Research Laboratory (United States)

Novel Detection Strategies for Chemical Detection

Jason A. Guicheteau, U.S. Army Edgewood Chemical Biological Center (United States)

Radiological and Nuclear Detection

James G. Placke, Jr., Y-12 National Security Complex (United States)

Nanotechnology for Standoff Detection and Counterterrorism

Operations I: Joint Session with Conference 8373

Michael K. Rafailov, The Reger Group (United States)

Thomas G. Thundat, University of Alberta (Canada)

Nanotechnology for Standoff Detection and Counterterrorism

Operations II: Joint Session with Conference 8373

Michael K. Rafailov, The Reger Group (United States)

Thomas G. Thundat, University of Alberta (Canada) 


\section{Introduction}

The thirteenth meeting of the Chemical, Biological, Radiological, Nuclear, and Explosives (CBRNE) Sensing conference was far from "unlucky". SPIE's decision to move the Defense Security + Sensing Symposium from Orlando to Baltimore was very good for this conference. The CBRNE Sensing conference had more submitted papers this year than any previous meeting. Likewise the quality of the papers remained quite high. All in all, I am quite pleased with the conference this year.

While the titles of the individual sessions this year appear similar to last year's meeting, the contributed papers reflect shifts in funded research over the past few years. The keynote address was given by Dr. Franca Jones from the Office of Science and Technology Policy (OSTP), Executive Office of the President, on Biosurveillance. While the first day of the conference focused on bio-detection, many of the papers highlighted recent policy and funding shifts away from developing stand-off biological detection using LIDAR to more disease monitoring and point-of-care diagnosis. Explosives detection remains a popular forum where groups across the inter-agency and academia are reporting on some exciting advances in point and stand-off detection of traditional and homemade (HME) explosives. The number of traditional chemical sensing papers was actually down this year, reflecting a downturn in defense funding in chemical warfare agent sensor development. The radiological and nuclear sensing session continues to grow in technical strength and attendee popularity. We also held a joint session with the Micro and Nanotechnology Sensors, Systems, and Applications IV conference on the development of nanosensors for counter-terrorism operations.

There continues to be interest in reliable methodologies and technologies for point- and stand-off detection of chemical, biological, radiological, special nuclear, and explosive (CBRNE) materials. This conference remains an important forum where diverse organizations and interests can share their labors to develop chemical and biological detection capabilities for the defense, medical, law enforcement, explosive ordinance disposal (EOD), environmental protection, industrial and critical infrastructure protection, and food processing communities.

As always, a tremendous 'thank you' to my program committee. I would not be able to organize and run this conference without their help.

Augustus Way Fountain III, Ph.D. 
Proc. of SPIE Vol. 8358 835801-12

Downloaded From: https://www.spiedigitallibrary.org/conference-proceedings-of-spie on 26 Apr 2023 Terms of Use: https://www.spiedigitallibrary.org/terms-of-use 